\title{
Role of LncRNA-AF085935, IL-10 and IL-17 in Rheumatoid Arthritis Patients With Chronic Hepatitis C
}

\author{
Dina Sabrya, e, Azza Elamir ${ }^{\mathrm{b}}$, Rania Hosny Mahmoud ${ }^{\mathrm{b}}$, \\ Ahmed Ali Abdelazizc ${ }^{c}$ Wael Fathy ${ }^{d}$
}

\begin{abstract}
Background: The current study aimed at testing the effect of corticosteroid therapy on serum levels of interleukin-10 (IL-10) and IL-17 as well as lncRNA-AF085935 in patients of rheumatoid arthritis (RA) associated with hepatitis $\mathrm{C}$ virus (HCV) and evaluating the usefulness of using these parameters to predict the therapeutic efficacy of steroids in these patients.
\end{abstract}

Methods: Thirty healthy control subjects and 65 chronic HCV patients with RA were included in our study. Patients were subjected to clinical examination, abdominal ultrasound, and liver biopsy and received 6-methyl-prednisolone (PDN) $16 \mathrm{mg}$ /day for 48 weeks. Blood samples were collected from all subjects and serum was separated to assess IL-10 and IL-17 by ELISA and HCV RNA and lncRNAAF085935 by qRT-PCR.

Results: Our study revealed that there were significant increases in serum levels of IL-10, IL-17 and lncRNA-AF085935 in RA patients associated with HCV compared with healthy control subjects. Also there were significant increases in serum levels of IL-10 and HCV RNA and a significant decrease in serum level of IL-17 in patients after corticosteroid therapy, while lncRNA-AF085935 is not significantly changed.

Conclusion: LncRNA-AF085935 might be a useful candidate biomarker for the early detection of RA associated with $\mathrm{HCV}$, providing potential new strategies for early screening and therapy of these patients. IL-17 is a non-invasive prognostic marker to predict the effi-

Manuscript accepted for publication January 30, 2017

${ }^{a}$ Medical Biochemistry and Molecular Biology Department, Faculty of Medicine, Cairo University, Cairo, Egypt

bMedical Biochemistry Department, Faculty of Medicine, Fayoum University, Al Fayoum, Egypt

'Rheumatology and Rehabilitation Department, Faculty of Medicine, Alazhar University, Cairo, Egypt

dTropical Medicine Department, Faculty of Medicine, Beni Suef University, Beni Suef, Egypt

${ }^{\mathrm{e} C}$ Corresponding Author: Dina Sabry, Medical Biochemistry and Molecular Biology Department, Faculty of Medicine, Cairo University, Cairo, Egypt.

Email: dinasabry@kasralainy.edu.eg

doi: https://doi.org/10.14740/jocmr2896w cacy of corticosteroid therapy in RA patients associated with chronic hepatitis $\mathrm{C}$.

Keywords: Rheumatoid arthritis; HCV; IL-10; IL-17; LncRNAAF085935

\section{Introduction}

Hepatitis $\mathrm{C}$ virus $(\mathrm{HCV})$ is a hepatotropic non-cytopathic positive strand RNA virus, which is considered the main cause of chronic hepatitis, cirrhosis, and hepatocellular carcinoma (HCC), affecting over 150 million people worldwide. In Egypt, the condition is even worse as just about every family is touched by hepatitis C. It kills an estimated 40,000 Egyptian per year where at least 1 in every 10 of the population aged $15-59$ is infected [1]. Egypt has the top ranks in prevalence of HCV globally (15\%) [2].

$\mathrm{HCV}$ infection is more than just a liver disease; several extrahepatic manifestations have been associated with chronic HCV infection. These include numerous rheumatic, hematologic, renal, dermatologic and autoimmune manifestations [3-5]. Rheumatic manifestations were found in $31 \%$ subjects infected with $\mathrm{HCV}$ in an Israeli study [6]. Rheumatic manifestations associated with HCV infection include arthralgia, myalgia, arthritis, vasculitis and fibromyalgia [6-9]. In addition, associations have been reported between HCV infection and other rheumatic and autoimmune diseases including systemic lupus, Sjogren's syndrome and anti-phospholipid syndrome $[8,10]$.

As the prevalence of $\mathrm{HCV}$ infection is high in the general population, it is frequent to use corticosteroids in $\mathrm{HCV}$-infected patients for different diseases which sometimes are associated to the virus itself. In chronic hepatitis $\mathrm{C}$ related autoimmune hepatitis, the clinician must face the challenge of treating with corticosteroids versus treating HCV with combined therapy. Interferon may worsen the autoimmune component $[11,12]$ and corticosteroids might increase HCV RNA and worsen the clinical evolution of chronic hepatitis C. However, the effect of steroids on chronic hepatitis $\mathrm{C}$ has not been fully determined, and there is not enough information to consider steroids as beneficial or harmful drugs on natural history of chronic hepatitis C [13]. 
Several articles have been published on this issue. Most of the reported studies were performed with low numbers of subjects using high-dose corticosteroids and seemed to reduce aspartate aminotransferase (AST) and alanine aminotransferase (ALT) at the expense of increasing HCV RNA [14, 15]. However, the effect of low-dose corticosteroids on histological activity and HCV RNA kinetics might be different [13].

Rheumatoid arthritis (RA) is a chronic, systemic, autoimmune disorder of unknown cause, which primarily affects the peripheral joints causing inflammation (arthritis) in a symmetric pattern [16]. Constitutional symptoms of the disease include fatigue, malaise and morning stiffness. Extraarticular involvement of organs such as the skin, heart, lungs and eyes can be significant. Moreover, RA causes joint destruction and thus often leads to considerable morbidity and mortality [17].

The worldwide incidence of RA is approximately three cases per 10,000 and the prevalence rate is approximately $1 \%$ of adults, but its prevalence rate in Egypt is approximately $0.2 \%$ of adults. Moreover, the frequency of RA increases with age and peaks in persons aged $35-50$ years [18]. Egyptian RA patients were significantly younger, had more active disease, and were more functionally disabled. They showed more frequent use of NSAIDs, methotrexate and steroids when compared to non-Egyptians. Egyptian patients had the highest ever HCV prevalence [19].

Interleukin-10 (IL-10) is a multifunctional cytokine with potent immunoregulatory and anti-inflammatory properties. It prevents the release and function of a number of pro-inflammatory cytokines. Elevated serum levels of IL-10 have been observed in patients with untreated chronic $\mathrm{HCV}$ infection $[20,21]$. IL-10 is also a T-helper (Th)-2-type cytokine, and it has been suggested that an imbalance in the Th1/Th2 immune response could influence the clinical outcome and disease progression [22].

Pro-inflammatory cytokines, TNF- $\alpha$ and IL-1 are overproduced by macrophages, synovial fibroblasts and neutrophils and play an important role in the process of chronic inflammation and joint destruction [23]. Synovial fluid from patients with RA also contains detectable levels of anti-inflammatory cytokine IL-10, but they are insufficient to counterbalance the effect of pro-inflammatory cytokines. The cellular sources of IL-10 in the synovial tissue are macrophages and T cells [24].

RA patients showed significantly reduced IL-10 levels in serum in comparison to healthy donors, suggesting that IL-10 synthesis is depressed in RA [25]. In addition, patients with advanced RA had the lowest values of IL-10 in serum [26]. On the contrary, some studies have shown that concentration of IL-10 in sera of patients with RA is higher as compared to controls $[27,28]$.

IL-17A (IL-17) is one of T cell-derived cytokines produced by Th17 cells [29]. IL-17 is a powerful chemoattractant for neutrophils and has been reported to be involved in many immune processes, most notably in inducing and mediating proinflammatory responses, e.g. several autoimmune diseases, allergic diseases, asthma and pulmonary infection [30-32].

Compared with controls, serum IL-17 levels were significantly higher in chronically HCV infected patients [33]. This result goes with what has been reported previously that serum
IL-17 level was increased in liver injuries following chronic hepatitis and cirrhosis supporting a role for IL-17 as a chronic disease inducer in the pathogenesis and/or progression of liver fibrosis [34].

Among the complex network of inflammatory cells involved in the pathogenesis of RA, Th17 cells have recently been identified as key cells in the promotion of autoimmune processes, joint destruction and angiogenesis [35]. The hallmark of the Th17 subset is the production of IL-17A and IL17F, which share strong homology [36]. Therefore, IL-17A and IL-17F may play an important role in T cell-triggered inflammation by upregulating some of the gene products involved in cell activation, proliferation and growth, and it is an important inductor of various cytokines and chemokines that are crucial in regulating the inflammatory response [37].

LncRNAs were a class of newfound non-coding RNAs, shorter than 200 nucleotides in length and were widely depicted in the genome currently [38]. As the function of most lncRNAs remains largely unknown, through our study, we investigated the correlation between lncRNA-AF085935 expression level and the RA HCV sufferers with corticosteroid therapy.

\section{Patients and Methods}

\section{Total enrolment}

Thirty control healthy subjects and 65 chronic HCV patients with RA were recruited from outpatient clinic at rheumatology and tropical departments, faculty of medicine according to the following inclusion and exclusion criteria.

Inclusion criteria were: 1) adult male and female patients aged 38 - 40 years old; 2) chronic HCV infection for > 6 months with detectable serum quantitative HCV RNA and serum ALT above the laboratory defined upper limit of normal; 3) positive anti-CCP; 4) compensated liver disease and albumin within normal limits; 5) liver biopsy confirming a histological diagnosis consistent with HCV necroinflammatory score $($ METAVIR $) \geq 1$, and fibrosis score $\geq 1$.

Exclusion criteria were: 1) co-infection with HBV or HIV; 2) decompensated liver disease (Child-Pugh classification B or C); 3) autoimmune or metabolic liver disease; 4) renal or parathyroid disease; 5) patients with a value of alpha-fetoprotein $>$ $100 \mathrm{ng} / \mathrm{mL}$ to exclude presence of HCC.

\section{Study design}

The study population consisted of 30 healthy control and 65 HCV patients. The study was approved by the institutional ethical committee and written informed consent was obtained from all patients. Sixty-five HCV patients were assigned to receive 6-methyl-prednisolone (PDN) $16 \mathrm{mg} /$ day for 48 weeks [39]. All subjects were reviewed as outpatients at 4-week intervals and were monitored for 6 months after treatment.

Natural interferon-alpha versus its combination with PDN in the therapy of type II mixed cryoglobulinemia: a long-term, 
randomized, controlled study.

\section{Blood samples collection}

Five milliliter blood sample was driven from each subject enrolled in study and divided into two parts. The first part was collected into vacationer EDTA tubes to assess biochemical parameters as follows: AST, ALT, total bilirubin (T. Bil), direct bilirubin (D. Bil), albumin, alkaline phosphatase (ALKP), creatinine, and random blood sugar (RBS) were detected using Roche Hitachi 911 Chemistry Analyzer (Bunker Lake Blvd. Greater Minneapolis, St. Paul Area, USA). Hemoglobin $\mathrm{A} 1 \mathrm{c}(\mathrm{HbA} 1 \mathrm{c})$, prothrombin concentrate (PC), and international normalized ratio (INR) were detected using kits (Stanbio Laboratary, Boerne, TX, USA). Hemoglobin ( $\mathrm{Hb}$ ), total leucocytes count (TLC), absolute neutrophil counts (ANC), and platelets were detected by cell counter (Sysmex XT-4000i Automated Hematology Analyzer, Lincolnshire, IL, USA). Thyroid-stimulating hormone (TSH) and alpha-fetoprotein (AFP) were detected using ELISA kits (DRG International Inc., Springfield, NJ, USA). Hepatic fibrosis metavir score was used to evaluate liver inflammation A (0-3), fibrosis F (04 ) and size $S(0-4)$. The second part was collected into another vacationer tube without EDTA to assess IL-10, IL-17 serum levels, to extract HCV RNA using the QIAamp Viral RNA Mini Kit (QIAgen, Hilden, Germany) for HCV quantitative PCR by TaqMan assay AgPath-ID ${ }^{\mathrm{TM}}$ one-step RT-PCR kit (Applied Biosystems, Foster City, CA, USA) and quantitative expression of long non-coding RNA (lncRNA-AF085935) by real-time PCR.

\section{IL-10 and IL-17 levels assessment}

IL-10 and IL-17 serum levels were assessed using ELISA kit (DRG International Inc., Springfield, NJ, USA). All protocols followed the manufacturer's instructions. Each ELISA test was performed in triplicate, with an illustrative standards curve done in the same run and the mean absorbance computed from the average for three wells normalized to a zero calibrator well.

\section{LncRNA-AF085935 expression}

Real-time qRT-PCR was used to detect lncRNA-AF085935 level by the SensiFAST ${ }^{\mathrm{TM}}$ SYBR ${ }^{\circledR}$ Hi-ROX One-Step Kit, catalog no. PI-50217 V, UK. Ten microliters RNA was prepared as templates for the reverse transcription reaction and the PCR reaction in one-step RT-PCR reaction. Samples were analyzed in duplicate, and non-template controls were included. The thermal cycling conditions were as follows: $50{ }^{\circ} \mathrm{C}$ for $15 \mathrm{~min}$ one cycle (for reverse transcriptase), $95^{\circ} \mathrm{C}$ at $10 \mathrm{~min}$ for RT enzyme inactivation, then 45 cycles at $93^{\circ} \mathrm{C}$ for $15 \mathrm{~s}, 54^{\circ} \mathrm{C}$ for 30 $\mathrm{s}$, and $72^{\circ} \mathrm{C}$ for $30 \mathrm{~s}$. $\beta$-actin was used as control. The sequence of IncRNA-AF085935 primers was forward 5'-CAGGGCAGCAAGGTGTTTTC-3' and reverse 5'-TTGGTGGGTTGCCTGATACC-3' (Genebank accession no. NG009286.1) and $\beta$-actin
Table 1. Demographic Characters in Different Study Groups

\begin{tabular}{llll}
\hline Variables & $\begin{array}{l}\text { Cases }(\mathbf{n}=\mathbf{6 5}), \\
\text { mean } \pm \text { SD }\end{array}$ & $\begin{array}{l}\text { Control }(\mathbf{n}=\mathbf{3 0}), \\
\text { mean } \pm \text { SD }\end{array}$ & P-value \\
\hline Age (years) & $39.4 \pm 11.7$ & $41.5 \pm 8.4$ & 0.4 \\
BMI & $27.6 \pm 2.1$ & $26.1 \pm 3$ & 0.1 \\
Sex, no. (\%) & & & \\
\multicolumn{1}{c}{ Male } & $47(72.3 \%)$ & $19(63.3 \%)$ & 0.5 \\
\multicolumn{1}{c}{ Female } & $18(27.7 \%)$ & $11(36.7 \%)$ & \\
\hline
\end{tabular}

was 5'-forward 5'-GGCGGCACCACCATGTACCCT-3' and reverse 5'-AGG GGCCGGACTCGTCATACT-3' (Genebank accession no. NM001101.3).

The amplification specific was confirmed by melting curve analysis. The relative level of lncRNAs was normalized to $\beta$-actin and calculated by using the $-\Delta \mathrm{Ct}$ method.

\section{Statistical analysis}

Data were collected and coded to facilitate data manipulation and double entered into Microsoft Access and data analysis was performed using SPSS software version 18 under windows 7. Simple descriptive analysis was in the form of numbers and percentages for qualitative data, and arithmetic means as central tendency measurement, standard deviations as measure of dispersion for quantitative parametric data, and inferential statistic test. Independent Student's $t$-test was used to compare measures of two independent groups of quantitative data. Paired $t$-test was used to compare two dependent quantitative data. Chi-square test was used to compare two of more than two qualitative groups. The level $\mathrm{P} \leq 0.05$ was considered the cut-off value for significance.

\section{Results}

There is no statistically significant difference with P-value $>$ 0.05 between cases and controls as regards age, sex and BMI, which indicates proper matching between two study groups (Table 1).

There is statistically significant difference with $\mathrm{P}$-value $<$ 0.05 between cases and controls as regards AST, ALT, total bilirubin, ALKP, PC, AFP, Hb, TLC, and platelets with high mean of ALT, AST, AFP, HB, TLC, and platelets and low mean of total bilirubin, ALKP and PC among cases. On the other hand, there is no statistically significant difference with P-value > 0.05 as regards level of direct bilirubin, albumin, creatinine, HbAlc, TSH, RBS, and INR level (Table 2).

Percentage of liver biopsy and ultrasound findings were illustrated in Figures 1 and 2.

There is statistically significant difference with $\mathrm{P}$-value $<$ 0.05 between cases before and after treatment as regards $\mathrm{HCV}$ RNA with high mean after treatment. There is statistically significant difference with P-value $<0.05$ between cases before and after treatment and controls as regards level of IL-10 and 
Table 2. Laboratory Investigations in Different Studied Groups

\begin{tabular}{llll}
\hline Variables & Cases $(\mathbf{n}=\mathbf{6 5})$, mean \pm SD & Control $(\mathbf{n}=\mathbf{3 0})$, mean \pm SD & P-value \\
\hline AST & $45.1 \pm 14.6$ & $27.1 \pm 7.5$ & $<0.001$ \\
ALT & $52.7 \pm 10.6$ & $26.3 \pm 7.8$ & $<0.001$ \\
Total bilirubin & $0.74 \pm 0.16$ & $0.96 \pm 0.21$ & $<0.001$ \\
Direct bilirubin & $0.23 \pm 0.11$ & $0.26 \pm 0.14$ & 0.2 \\
Albumin & $4.1 \pm 0.48$ & $4.3 \pm 0.59$ & 0.06 \\
Alkaline phosphate & $68.9 \pm 24.6$ & $81.9 \pm 28.2$ & 0.02 \\
PC & $0.88 \pm 0.07$ & $0.91 \pm 0.06$ & 0.02 \\
INR & $1.08 \pm 0.10$ & $1.1 \pm 0.12$ & 0.3 \\
Creatinine & $0.93 \pm 0.29$ & $0.93 \pm 0.29$ & 0.9 \\
HbA1c & $5.4 \pm 0.78$ & $5.33 \pm 0.94$ & 0.8 \\
TSH & $1.63 \pm 0.98$ & $1.89 \pm 1.5$ & 0.3 \\
AFP & $13.2 \pm 6.3$ & $3.33 \pm 2.1$ & $<0.001$ \\
RBS & $87.6 \pm 23.3$ & $95.7 \pm 26.2$ & 0.1 \\
Hb $(g)$ & $13.2 \pm 2.3$ & $10.8 \pm 1.1$ & $<0.001$ \\
TLC $(\times 1,000)$ & $6.4 \pm 1.9$ & $4.2 \pm 1.2$ & $<0.001$ \\
Platelets & $273.6 \pm 103.5$ & $181.1 \pm 69.4$ & $<0.001$ \\
\hline
\end{tabular}

IL-17. There is statistically significant difference with P-value $<0.05$ between cases before treatment and controls and between cases after treatment and controls as regards lncRNAAF085935 with high mean among cases. On the other hand, there is no statistically significant difference with P-value > 0.05 as regards lncRNA-AF085935 before and after treatment (Table 3).

There is no statistically significant correlation with P-value $>0.05$ between HCV RNA level and all parameters before and after treatment (Table 4).

This table shows that IL-17 after treatment had the highest sensitivity, specificity, and accuracy in predicting the efficacy of steroid therapy in chronic HCV patients with RA (Table 5 and Figs. 3, 4 and 5).

\section{Discussion}

RA is a chronic inflammatory disorder in which the articular joints are gradually destroyed [40].

The relationship between HCV and rheumatic diseases is complex and represents both a diagnostic and therapeutic problem to rheumatologists [41]. Management of RA is complicated with the highly significant difference regarding

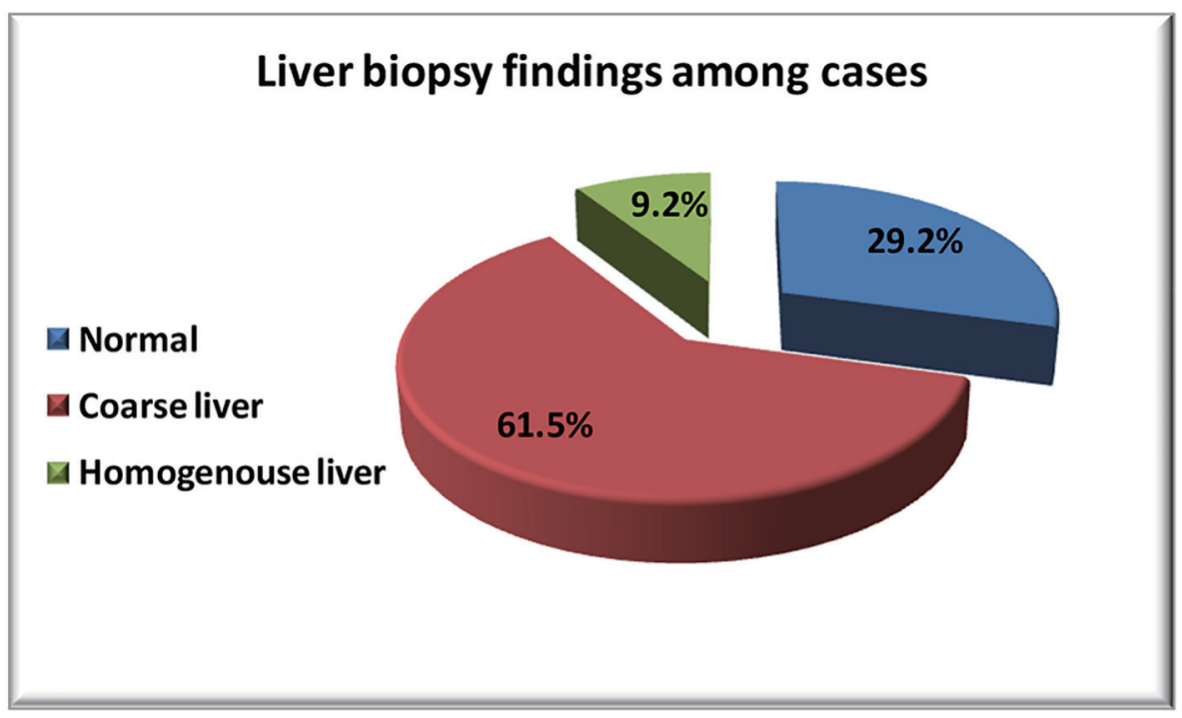

Figure 1. Liver biopsy findings among cases. 


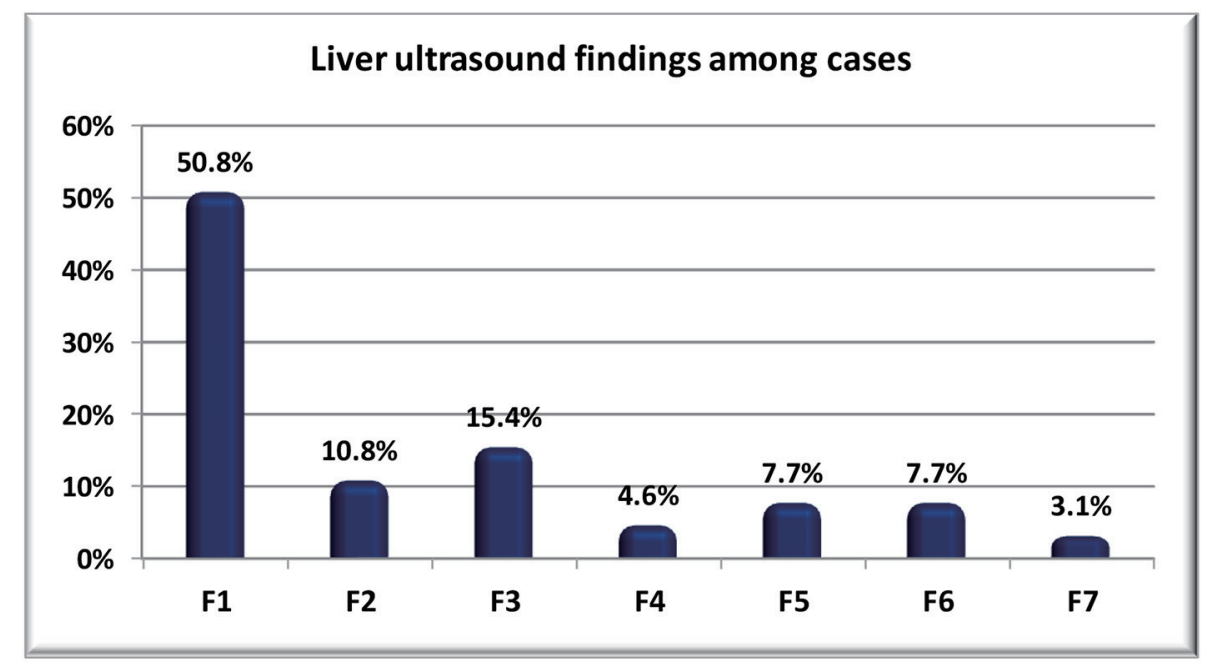

Figure 2. Liver ultrasound findings among cases.

Table 3. HCV RNA, IL-10, IL-17 and IncRNA-AF085935 in Different Study Groups

\begin{tabular}{lllll}
\hline Variables & $\begin{array}{l}\text { G1: before treatment } \\
(\mathbf{n}=\mathbf{6 5}), \text { mean } \pm \mathbf{S D}\end{array}$ & $\begin{array}{l}\text { G2: after treatment } \\
(\mathbf{n}=\mathbf{6 5}), \text { mean } \pm \text { SD }\end{array}$ & $\begin{array}{l}\text { G3: control } \\
(\mathbf{n}=\mathbf{3 0}), \text { mean } \pm \text { SD }\end{array}$ & P-value \\
\hline HCV RNA & $323,955 \pm 337,313.6$ & $1418,729.7 \pm 2,380,203.2$ & & $0.001^{\mathrm{a}}$ \\
IL-10 & $68.5 \pm 24.7$ & $201.4 \pm 31.9$ & $51.9 \pm 20.3$ & $<0.001^{\mathrm{a}, \mathrm{b}, \mathrm{c}}$ \\
IL-17 & $227.9 \pm 35.5$ & $112.4 \pm 28.1$ & $53.4 \pm 20.7$ & $<0.001^{\mathrm{a}, \mathrm{b}, \mathrm{c}}$ \\
LncRNA-AF085935 & $4.12 \pm 0.67$ & $4.17 \pm 0.66$ & $1.84 \pm 1.11$ & $<0.001^{\mathrm{b}, \mathrm{c}}$ \\
\hline
\end{tabular}

aSignificance between G1 and G2. bSignificance between G1 and G3. 'Significance between G2 and G3.

prevalence of HCV in Egyptians. Such a finding was expected as $\mathrm{HCV}$ is a global health threat in Egypt, and the country is the largest reservoir of $\mathrm{HCV}$ in the world [19]. Patients with rheumatic diseases have an increased susceptibility to infections including $\mathrm{HCV}$, due to immunosuppression caused by the disease itself and by drugs used in their treatment [42], in addition to their high exposure to numerous invasive diagnostic and therapeutic procedures, including blood transfusions [43].

The current study aimed at testing the effect of corticosteroid therapy on serum levels of IL-10 and IL-17 as well as lncRNA-AF085935 in patients of RA associated with HCV and evaluating the usefulness of using these parameters to predict the therapeutic efficacy of steroids in these patients.

In this study, it was found that our patients significantly had lower pretreatment HCV RNA level which increased markedly after the administration of systemic steroid therapy. This agrees with Cansu et al who demonstrated that glucocorticoids and immunosuppressive drugs that are commonly used in the management of rheumatic diseases can increase $\mathrm{HCV}$ replication [44]. In another study, corticosteroids rose HCV RNA levels when used in treatment of HCV patients [13]. There is one study in which corticosteroid treatment was applied at clinically relevant concentrations $(1-10 \mathrm{nM})$ to the $\mathrm{HCV}$ replicon model. Not only did it not enhance but resulted in a slight reduction of $\mathrm{HCV}$ replication (over $41 \%$ reduction in HCV RNA levels) [45].

Our results revealed that the serum levels of IL-10 were significantly higher in our patients of RA associated with $\mathrm{HCV}$ than in healthy individuals. This increase was in partial agreement with Lacki et al [27] and St Clair [28] who detected that concentration of IL-10 in sera of patients with RA is higher as compared to controls and in partial agreement with what has been reported by Jia et al who reported that increased serum level of IL-10 is present in chronic HCV patients [21]. Moreover, a significant high level of serum IL-10 was found in our patients after steroid therapy.

The result of the current study was in contrast with the study done by Lapadula et al who detected that RA patients showed significantly reduced IL-10 levels in serum in comparison to healthy donors, suggesting that IL-10 synthesis is depressed in RA [25]. In addition, patients with advanced RA had the lowest values of IL-10 in serum [26]. On the other hand, a significant decrease in plasma IL-10 level was reported

Table 4. Correlation Between HCV RNA Level With Other Parameters Before and After Treatment Among Study Group

\begin{tabular}{lll}
\hline \multirow{2}{*}{ Variables } & \multicolumn{2}{c}{$\mathbf{r}$ (P-value) } \\
\cline { 2 - 3 } & $\begin{array}{l}\text { HCV-PCR before } \\
\text { treatment }\end{array}$ & $\begin{array}{l}\text { HCV-PCR after } \\
\text { treatment }\end{array}$ \\
\hline IL-10 & $0.02(0.8)$ & $0.01(0.9)$ \\
IL-17 & $0.05(0.7)$ & $-0.17(0.2)$ \\
\hline LncRNA-AF085935 & $-0.033(0.9)$ & $0.04(0.8)$ \\
\hline
\end{tabular}


Table 5. Sensitivity and Specificity of Different Parameters in Predicting the Efficacy of Steroid Therapy in Patients

\begin{tabular}{lllll}
\hline Variable & Sensitivity & Specificity & Accuracy & Cut-off point \\
\hline IL-10 & & & \\
Before & $77.3 \%$ & $23.3 \%$ & $51 \%$ & 45 \\
After & $72.7 \%$ & $30.2 \%$ & $53.9 \%$ & 175.1 \\
IL-17 & & & \\
Before & $72.7 \%$ & $25.6 \%$ & $42 \%$ & 198.5 \\
After & $81.8 \%$ & $23.3 \%$ & $62.1 \%$ & 196.8 \\
LncRNA-AF085935 & & & \\
Before & $63.6 \%$ & $27.2 \%$ & $48.5 \%$ & 3.74 \\
After & $68.2 \%$ & $20.9 \%$ & $38.4 \%$ & 3.63 \\
\hline
\end{tabular}

previously in chronic hepatitis $\mathrm{C}$ patients [46].

The cellular sources of IL-10 in synovial tissue are macrophages and $\mathrm{T}$ cells [24]. The pro-inflammatory cytokines themselves appear to trigger the synthesis of IL-10 as evidenced by experiments in which adding TNF- $\alpha$ or IL-1 has been shown to augment IL-10 production [47]. IL-10 acts to curb the inflammatory response, so it serves to inhibit synovial inflammation [28]. Synovial fluid from patients with RA contains detectable levels of IL-10 mRNA and protein [24]. The predominant source of IL-10 in the synovial fluid is the mononuclear cell (MNC) [48]. The blood MNCs from patients with RA spontaneously produce IL-10 in culture [49] and represent the main source of circulatory IL-10 so the median serum level of IL-10 is increased in patients with RA compared with that of healthy controls [50].

IL-10 is an important anti-inflammatory cytokine that is secreted from Th2 cells. The levels of IL-10 production determine the regulation of the immune response and the balance between the inflammatory and humoral responses [51]. The Th1 cell-mediated immune response is a key factor in the protection against $\mathrm{HCV}$ infection [52]. Conversely, patients presenting with a Th2 response evolve into chronicity [53] and are less likely to eliminate viremia following therapy [54]. Because it has been shown that the Th1 and Th2 responses are not completely independent, Th2 cytokines such as IL-10 can downregulate the cell-mediated immune mechanisms that

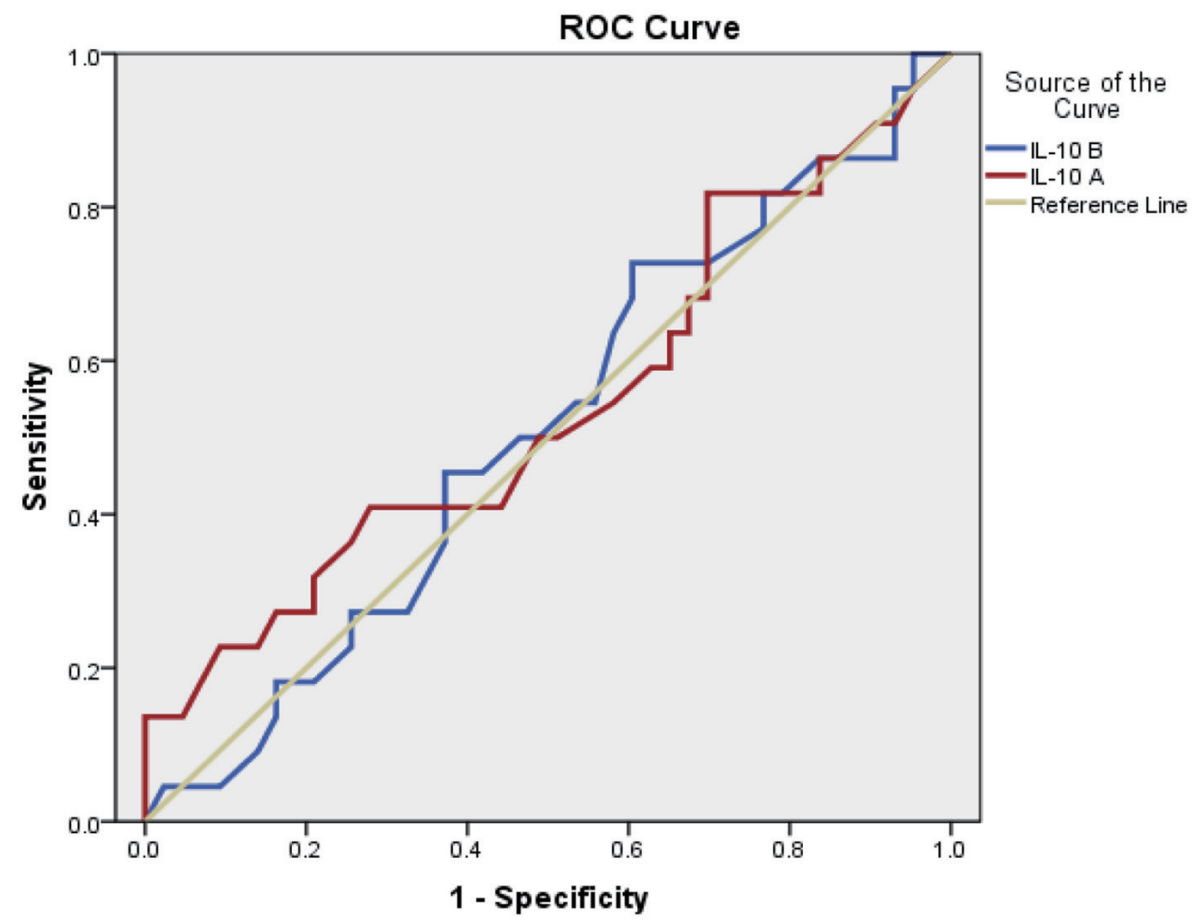

Diagonal segments are produced by ties.

Figure 3. ROC curve for IL-10 before and after treatment. 


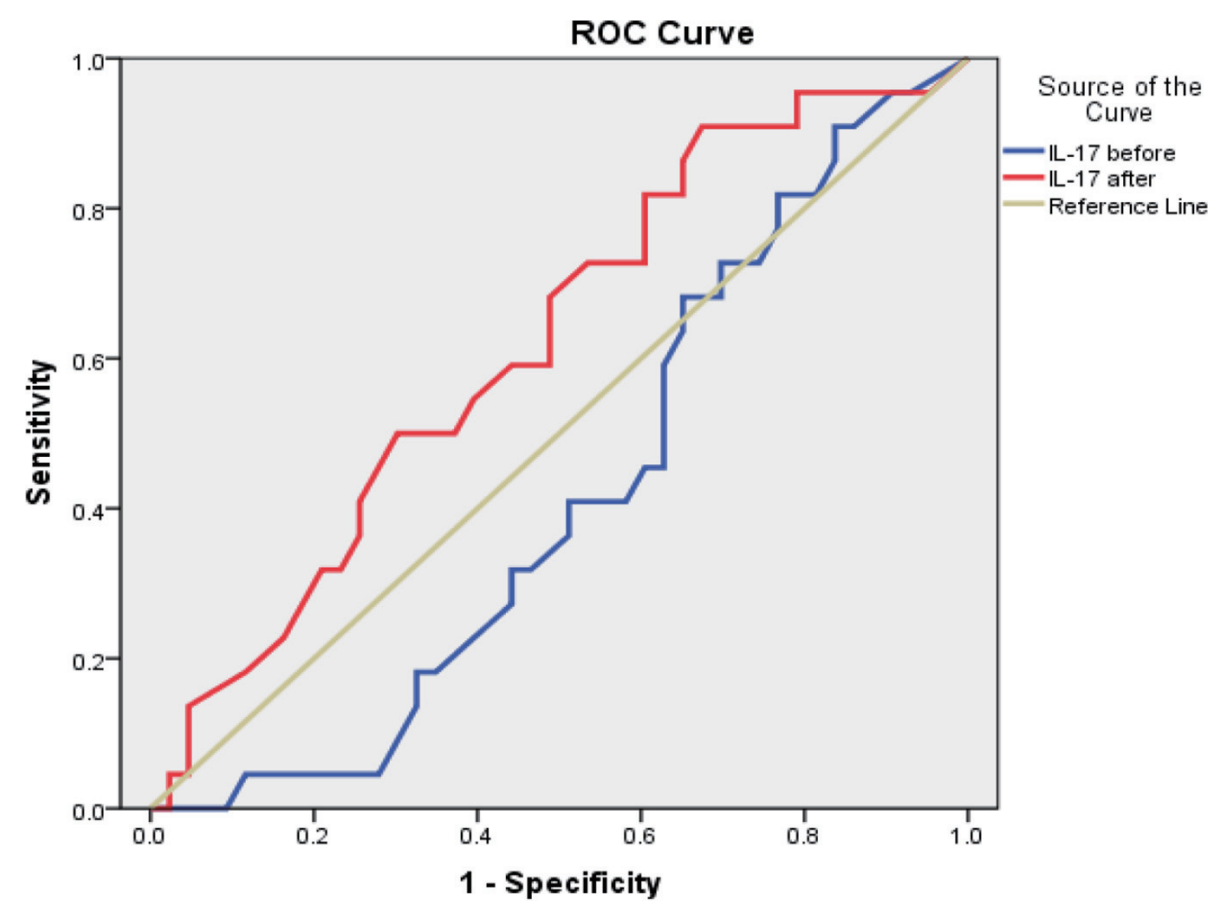

Diagonal segments are produced by ties.

Figure 4. ROC curve for IL-17 before and after treatment.

are important for host defense against viral infections [55]. The persistent production of IL-10 as a result of stimulation by HCV proteins leads to skewing from a protective Th1 response, which results in viral evasion and chronic infection [56]. A shift toward a Th1 cytokine profile is implicated in a more benign and favorable course of HCV infection [57].

Our results regarding the increase of IL-10 following steroid therapy was in a harmony with the study done by Peek et al who reported that secretion of endogenous IL-10 might be augmented by glucocorticoids (GCS) [58]

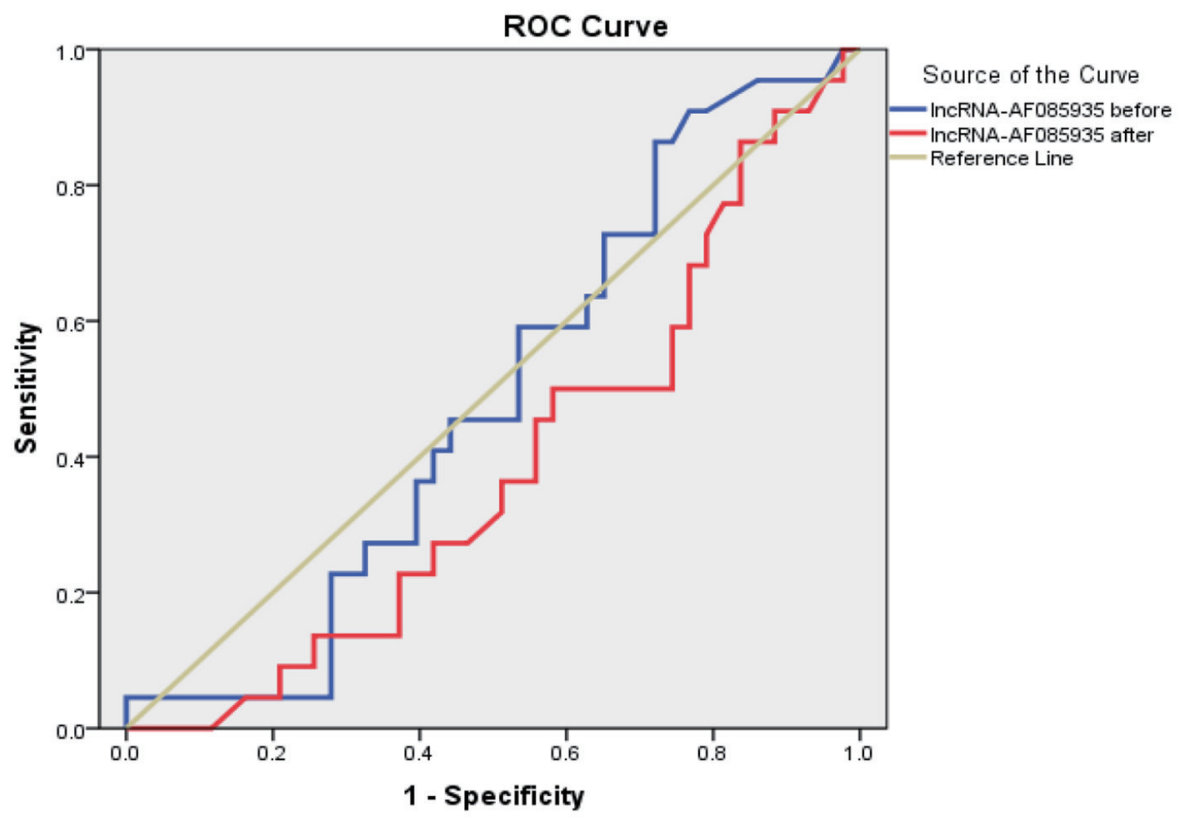

Diagonal segments are produced by ties.

Figure 5. ROC curve for IncRNA-AF085935 before and after treatment. 
Our results revealed that the serum levels of IL-17 were significantly higher in our patients than in healthy individuals. Moreover, the serum IL-17 level was observed to be significantly lower in patients after steroid therapy than in them before treatment. Th17 cells produce the cytokine IL-17, which induces the production of several pro-inflammatory cytokines, such as TNF- $\alpha$ and IL- 6 , chemokines, and some other additional novel factors responsible for RA and other autoimmune diseases [59]. IL-17 has also been found in the synovial membrane and synovial fluid of RA patients [60]. So in chronic inflammatory conditions such as RA, the levels of pro-inflammatory cytokines are increased [61], possibly to provide additional energy resources for the activated immune system [62]. On the other hand, it was found that serum IL-17 levels were significantly higher in chronically $\mathrm{HCV}$ infected patients than controls [33]. This higher serum IL-17 in patients with chronic liver disease goes with what has been reported previously that serum IL-17 level was increased in liver injuries following chronic hepatitis and cirrhosis supporting a role for IL-17 as a chronic disease inducer in the pathogenesis and/or progression of liver fibrosis [34]. Administration of corticosteroid therapy is associated with a decrease in inflammatory markers levels due to its anti-inflammatory effects [63]. Our results detected that the high expression of IncRNA-AF085935 in our patients of RA associated with HCV is highly significant than in healthy individuals who show underexpression of this lncRNA. The high upregulated AF085935 was not changed in patients following steroid therapy. We suggest that lncRNAAF085935 may serve as a potential biomarker for the detection of RA associated with HCV patients. More studies about the biological regulatory roles of IncRNAs have demonstrated that some lncRNAs can influence the roles of their neighboring protein-coding genes by acting as biological enhancers [64]. In addition, some lncRNAs have been tightly linked between gene regulation and nuclear organization [65].

In conclusion, corticosteroid treatment caused a significant decrease in the serum levels of IL-17 and a significant increase in IL-10 and HCV RNA. However, our findings provide evidence that serum levels of IL-10 are non-invasive prognostic markers to predict the efficacy of corticosteroid therapy in RA patients associated with chronic hepatitis C. As a member of lncRNAs, IncRNA-AF085935 was highly expressed in the serum of RA patients associated with HCV. This leads to an indication that lncRNA-AF085935 might be a useful candidate biomarker for the early detection of RA associated with HCV which may provide potential new strategies for early screening and therapy of these patients. Further studies are needed to clarify these conclusions. This knowledge could be used to develop new treatment options. Also, the population of enrolled patients and controls was relatively small, which needs a larger sample to further study to verify our results.

\section{References}

1. Wedemeyer H, Dore GJ, Ward JW. Estimates on HCV disease burden worldwide - filling the gaps. J Viral Hepat. 2015;22(Suppl 1):1-5.

2. Abdelsalam A, Rashed L, Salman T, Hammad L, Sabry
D. Molecular assessment of vitamin D receptor polymorphism as a valid predictor to the response of interferon/ ribavirin-based therapy in Egyptian patients with chronic hepatitis C. J Dig Dis. 2016;17(8):547-553.

3. Cacoub P, Renou C, Rosenthal E, Cohen P, Loury I, Loustaud-Ratti V, Yamamoto AM, et al. Extrahepatic manifestations associated with hepatitis $\mathrm{C}$ virus infection. A prospective multicenter study of 321 patients. The GERMIVIC. Groupe d'Etude et de Recherche en Medecine Interne et Maladies Infectieuses sur le Virus de l'Hepatite C. Medicine (Baltimore). 2000;79(1):47-56.

4. Ramos-Casals M, Font J. Extrahepatic manifestations in patients with chronic hepatitis $\mathrm{C}$ virus infection. Curr Opin Rheumatol. 2005;17(4):447-455.

5. Sterling RK, Bralow S. Extrahepatic manifestations of hepatitis C virus. Curr Gastroenterol Rep. 2006;8(1):5359.

6. Buskila D, Shnaider A, Neumann L, Lorber M, Zilberman D, Hilzenrat N, Kuperman OJ, et al. Musculoskeletal manifestations and autoantibody profile in 90 hepatitis $\mathrm{C}$ virus infected Israeli patients. Semin Arthritis Rheum. 1998;28(2):107-113.

7. Buskila D. Hepatitis C-associated arthritis. Curr Opin Rheumatol. 2000;12(4):295-299.

8. Lormeau C, Falgarone G, Roulot D, Boissier MC. Rheumatologic manifestations of chronic hepatitis $\mathrm{C}$ infection. Joint Bone Spine. 2006;73(6):633-638.

9. Buskila D. Hepatitis C-associated rheumatic disorders. Rheum Dis Clin North Am. 2009;35(1):111-123.

10. Ramos-Casals M, Jara LJ, Medina F, Rosas J, CalvoAlen J, Mana J, Anaya JM, et al. Systemic autoimmune diseases co-existing with chronic hepatitis $\mathrm{C}$ virus infection (the HISPAMEC Registry): patterns of clinical and immunological expression in 180 cases. J Intern Med. 2005;257(6):549-557.

11. Vento S, Di Perri G, Garofano T, Cosco L, Concia E, Ferraro T, Bassetti D. Hazards of interferon therapy for HBVseronegative chronic hepatitis. Lancet. 1989;2(8668):926.

12. Papo T, Marcellin P, Bernuau J, Durand F, Poynard T, Benhamou JP. Autoimmune chronic hepatitis exacerbated by alpha-interferon. Ann Intern Med. 1992;116(1):51-53.

13. Romero Gutierrez M, del Campo Terron S, Moreno Zamora A, Sanchez Ruano JJ, Artaza Varasa T, Barcena Marugan R. Does low-dose prolonged steroid therapy affect the natural history of chronic hepatitis C? J Med Virol. 2014;86(5):758-764.

14. McHutchison JG, Ponnudurai R, Bylund DL, Anguiano A, Pockros PJ, Mondala T, Wilkes LB. Prednisone withdrawal followed by interferon alpha for treatment of chronic hepatitis $\mathrm{C}$ infection: results of a randomized controlled trial. J Clin Gastroenterol. 2001;32(2):133137.

15. Schiano TD, Te HS, Thomas RM, Hussain H, Bond K, Black M. Results of steroid-based therapy for the hepatitis C-autoimmune hepatitis overlap syndrome. Am J Gastroenterol. 2001;96(10):2984-2991.

16. Majithia V, Geraci SA. Rheumatoid arthritis: diagnosis and management. Am J Med. 2007;120(11):936-939.

17. Sacks JJ, Helmick CG, Langmaid G. Deaths from arthri- 
tis and other rheumatic conditions, United States, 19791998. J Rheumatol. 2004;31(9):1823-1828.

18. Helmick CG, Felson DT, Lawrence RC, Gabriel S, Hirsch $\mathrm{R}$, Kwoh CK, Liang MH, et al. Estimates of the prevalence of arthritis and other rheumatic conditions in the United States. Part I. Arthritis Rheum. 2008;58(1):15-25.

19. El-Zorkany B, Mokbel A, Gamal SM, Mousa M, Youssef M, Hmamouchi I. Comparison of comorbidities of the Egyptian rheumatoid arthritis patients to the global cohort of the COMORA study: a post-hoc analysis. Clin Rheumatol. 2016;35(5):1153-1159.

20. Cacciarelli TV, Martinez OM, Gish RG, Villanueva JC, Krams SM. Immunoregulatory cytokines in chronic hepatitis $\mathrm{C}$ virus infection: pre- and posttreatment with interferon alfa. Hepatology. 1996;24(1):6-9.

21. Jia HY, Du J, Zhu SH, Ma YJ, Chen HY, Yang BS, Cai HF. The roles of serum IL-18, IL-10, TNF-alpha and sIL$2 \mathrm{R}$ in patients with chronic hepatitis C. Hepatobiliary Pancreat Dis Int. 2002;1(3):378-382.

22. Sobue S, Nomura T, Ishikawa T, Ito S, Saso K, Ohara H, Joh T, et al. Th1/Th2 cytokine profiles and their relationship to clinical features in patients with chronic hepatitis C virus infection. J Gastroenterol. 2001;36(8):544-551.

23. Trifunovic J, Miller L, Debeljak Z, Horvat V. Pathologic patterns of interleukin 10 expression - a review. Biochem Med (Zagreb). 2015;25(1):36-48.

24. Isomaki P, Luukkainen R, Saario R, Toivanen P, Punnonen J. Interleukin-10 functions as an antiinflammatory cytokine in rheumatoid synovium. Arthritis Rheum. 1996;39(3):386-395.

25. Lapadula G, Iannone F, Dell'Accio F, Covelli M, Pipitone V. Interleukin-10 in rheumatoid arthritis. Clin Exp Rheumatol. 1995;13(5):629-632.

26. Avramescu C, Vere CC, Margaritescu C, Turculeanu A, Balasoiu M, Rogoz S. Cytokinin panel in rheumatoid arthritis and correlation with histological patterns of synovitis -- active type of disease. Rom J Morphol Embryol. 2005;46(2):87-92.

27. Lacki JK, Klama K, Porawska W, Mackiewicz SH, Muller W, Wiktorowicz K. Interleukin 10 inhibits interleukin 6 production and acute phase response in rheumatoid arthritis. Arch Immunol Ther Exp (Warsz). 1995;43(1):1114.

28. St Clair EW. Interleukin 10 treatment for rheumatoid arthritis. Ann Rheum Dis. 1999;58(Suppl 1):I99-I102.

29. Huang W, Na L, Fidel PL, Schwarzenberger P. Requirement of interleukin-17A for systemic anti-Candida albicans host defense in mice. J Infect Dis. 2004;190(3):624631.

30. Woltman AM, de Haij S, Boonstra JG, Gobin SJ, Daha $\mathrm{MR}$, van Kooten C. Interleukin-17 and CD40-ligand synergistically enhance cytokine and chemokine production by renal epithelial cells. J Am Soc Nephrol. 2000;11(11):2044-2055.

31. Toda M, Leung DY, Molet S, Boguniewicz M, Taha R, Christodoulopoulos P, Fukuda T, et al. Polarized in vivo expression of IL-11 and IL-17 between acute and chronic skin lesions. J Allergy Clin Immunol. 2003;111(4):875881 .
32. Louten J, Boniface K, de Waal Malefyt R. Development and function of TH17 cells in health and disease. J Allergy Clin Immunol. 2009;123(5):1004-1011.

33. Hassan EA, Abd El-Rehim ASE, Ahmed AO, Elsherbiny NM, Abo Elhagag NAE. The Impact of Serum Interleukin-17 on Chronic Hepatitis C and Its Sequelae. J Liver. 2014;3:163.

34. Chang Q, Wang YK, Zhao Q, Wang CZ, Hu YZ, Wu BY. Th17 cells are increased with severity of liver inflammation in patients with chronic hepatitis C. J Gastroenterol Hepatol. 2012;27(2):273-278.

35. Annunziato F, Cosmi L, Liotta F, Maggi E, Romagnani S. Type $17 \mathrm{~T}$ helper cells-origins, features and possible roles in rheumatic disease. Nat Rev Rheumatol. 2009;5(6):325331.

36. Hot A, Zrioual S, Toh ML, Lenief V, Miossec P. IL-17Aversus IL-17F-induced intracellular signal transduction pathways and modulation by IL-17RA and IL-17RC RNA interference in rheumatoid synoviocytes. Ann Rheum Dis. 2011;70(2):341-348.

37. Bogunia-Kubik K, Swierkot J, Malak A, Wysoczanska B, Nowak B, Bialowas K, Gebura K, et al. IL-17A, IL-17F and IL-23R Gene Polymorphisms in Polish Patients with Rheumatoid Arthritis. Arch Immunol Ther Exp (Warsz). 2015;63(3):215-221.

38. Zhao Y, Guo Q, Chen J, Hu J, Wang S, Sun Y. Role of long non-coding RNA HULC in cell proliferation, apoptosis and tumor metastasis of gastric cancer: a clinical and in vitro investigation. Oncol Rep. 2014;31(1):358-364.

39. Dammacco F, Sansonno D, Han JH, Shyamala V, Cornacchiulo $V$, Iacobelli AR, Lauletta $G$, et al. Natural interferon-alpha versus its combination with 6-methylprednisolone in the therapy of type II mixed cryoglobulinemia: a long-term, randomized, controlled study. Blood. 1994;84(10):3336-3343.

40. Yamamoto K, Yamada R. Lessons from a genomewide association study of rheumatoid arthritis. N Engl J Med. 2007;357(12):1250-1251.

41. El Garf A, El Zorkany B, Gheith R, Sheba H, Abdel Moneim G, El Garf K. Prevalence and clinical presentations of hepatitis $\mathrm{C}$ virus among patients admitted to the rheumatology ward. Rheumatol Int. 2012;32(9):2691-2695.

42. Barbosa VS, Silva NA, Martins RM. Hepatitis C virus seroprevalence and genotypes in patients with diffuse connective tissue diseases and spondyloarthropathies. Braz J Med Biol Res. 2005;38(5):801-805.

43. Pryor BD, Bologna SG, Kahl LE. Risk factors for serious infection during treatment with cyclophosphamide and high-dose corticosteroids for systemic lupus erythematosus. Arthritis Rheum. 1996;39(9):1475-1482.

44. Cansu DU, Kalifoglu T, Korkmaz C. Short-term course of chronic hepatitis $\mathrm{B}$ and $\mathrm{C}$ under treatment with etanercept associated with different disease modifying antirheumatic drugs without antiviral prophylaxis. J Rheumatol. 2008;35(3):421-424.

45. Henry SD, Metselaar HJ, Van Dijck J, Tilanus HW, Van Der Laan LJ. Impact of steroids on hepatitis C virus replication in vivo and in vitro. Ann N Y Acad Sci. 2007;1110:439-447. 
46. Gramenzi A, Andreone P, Loggi E, Foschi FG, Cursaro C, Margotti M, Biselli M, et al. Cytokine profile of peripheral blood mononuclear cells from patients with different outcomes of hepatitis $\mathrm{C}$ virus infection. J Viral Hepat. 2005;12(5):525-530.

47. Katsikis PD, Chu CQ, Brennan FM, Maini RN, Feldmann M. Immunoregulatory role of interleukin 10 in rheumatoid arthritis. J Exp Med. 1994;179(5):1517-1527.

48. van Roon JA, van Roy JL, Gmelig-Meyling FH, Lafeber FP, Bijlsma JW. Prevention and reversal of cartilage degradation in rheumatoid arthritis by interleukin-10 and interleukin-4. Arthritis Rheum. 1996;39(5):829-835.

49. Llorente L, Richaud-Patin Y, Fior R, Alcocer-Varela J, Wijdenes J, Fourrier BM, Galanaud P, et al. In vivo production of interleukin-10 by non-T cells in rheumatoid arthritis, Sjogren's syndrome, and systemic lupus erythematosus. A potential mechanism of B lymphocyte hyperactivity and autoimmunity. Arthritis Rheum. 1994;37(11):1647-1655.

50. Cush JJ, Splawski JB, Thomas R, McFarlin JE, SchulzeKoops H, Davis LS, Fujita K, et al. Elevated interleukin-10 levels in patients with rheumatoid arthritis. Arthritis Rheum. 1995;38(1):96-104.

51. Reuss E, Fimmers R, Kruger A, Becker C, Rittner C, Hohler T. Differential regulation of interleukin-10 production by genetic and environmental factors--a twin study. Genes Immun. 2002;3(7):407-413.

52. Lasarte JJ, Garcia-Granero M, Lopez A, Casares N, Garcia N, Civeira MP, Borras-Cuesta F, et al. Cellular immunity to hepatitis $\mathrm{C}$ virus core protein and the response to interferon in patients with chronic hepatitis C. Hepatology. 1998;28(3):815-822.

53. Koziel MJ. Cellular immune responses against hepatitis C virus. Clin Infect Dis. 2005;41(Suppl 1):S25-31.

54. Barrat FJ, Cua DJ, Boonstra A, Richards DF, Crain C, Savelkoul HF, de Waal-Malefyt $\mathrm{R}$, et al. In vitro generation of interleukin 10-producing regulatory $\mathrm{CD} 4(+) \mathrm{T}$ cells is induced by immunosuppressive drugs and inhibited by T helper type 1 (Th1)- and Th2-inducing cytokines. J Exp Med. 2002;195(5):603-616.

55. Sher A, Gazzinelli RT, Oswald IP, Clerici M, Kullberg M, Pearce EJ, Berzofsky JA, et al. Role of T-cell derived cytokines in the downregulation of immune responses in parasitic and retroviral infection. Immunol Rev. 1992;127:183-204.

56. Gerlach JT, Diepolder HM, Jung MC, Gruener NH, Schraut WW, Zachoval R, Hoffmann R, et al. Recurrence of hepatitis $\mathrm{C}$ virus after loss of virus-specific CD4(+) T-cell response in acute hepatitis C. Gastroenterology. 1999;117(4):933-941.

57. Sarih M, Bouchrit N, Benslimane A. Different cytokine profiles of peripheral blood mononuclear cells from patients with persistent and self-limited hepatitis $\mathrm{C}$ virus infection. Immunol Lett. 2000;74(2):117-120.

58. Peek EJ, Richards DF, Faith A, Lavender P, Lee TH, Corrigan $\mathrm{CJ}$, Hawrylowicz CM. Interleukin-10-secreting "regulatory" T cells induced by glucocorticoids and beta2-agonists. Am J Respir Cell Mol Biol. 2005;33(1):105111.

59. Bettelli E, Korn T, Oukka M, Kuchroo VK. Induction and effector functions of $\mathrm{T}(\mathrm{H}) 17$ cells. Nature. 2008;453(7198):1051-1057.

60. Li N, Wang JC, Liang TH, Zhu MH, Wang JY, Fu XL, Zhou JR, et al. Pathologic finding of increased expression of interleukin-17 in the synovial tissue of rheumatoid arthritis patients. Int J Clin Exp Pathol. 2013;6(7):13751379.

61. Straub RH, Cutolo M. Circadian rhythms in rheumatoid arthritis: implications for pathophysiology and therapeutic management. Arthritis Rheum. 2007;56(2):399-408.

62. Straub RH, Cutolo M, Buttgereit F, Pongratz G. Energy regulation and neuroendocrine-immune control in chronic inflammatory diseases. J Intern Med. 2010;267(6):543560 .

63. Alten R. Chronotherapy with modified-release prednisone in patients with rheumatoid arthritis. Expert Rev Clin Immunol. 2012;8(2):123-133.

64. Orom UA, Derrien T, Beringer M, Gumireddy K, Gardini A, Bussotti G, Lai F, et al. Long noncoding RNAs with enhancer-like function in human cells. Cell. 2010;143(1):46-58.

65. Quinodoz S, Guttman M. Long noncoding RNAs: an emerging link between gene regulation and nuclear organization. Trends Cell Biol. 2014;24(11):651-663. 